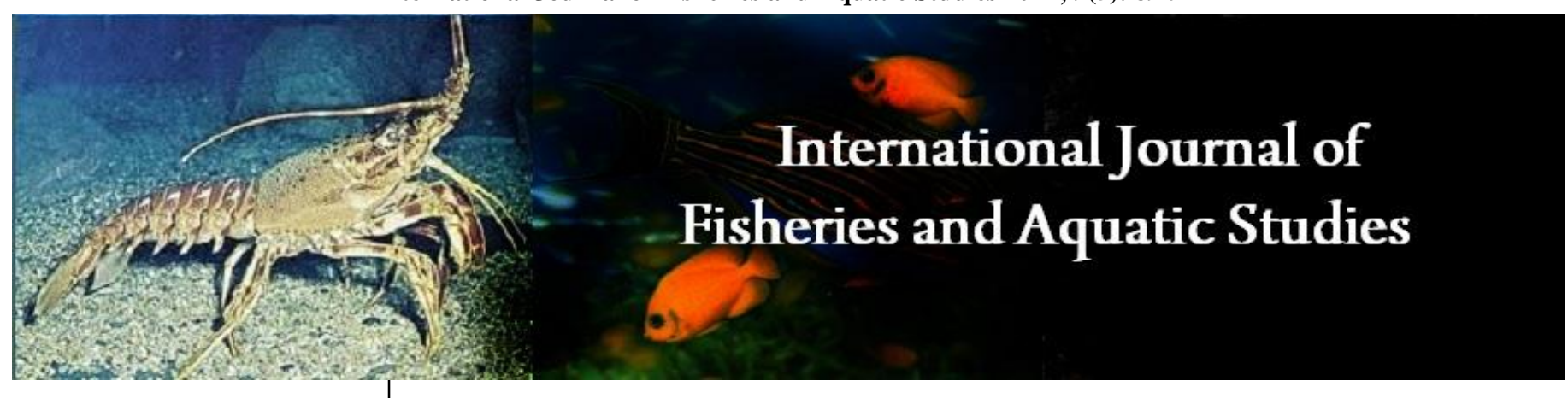

E-ISSN: 2347-5129

P-ISSN: 2394-0506

(ICV-Poland) Impact Value: 5.62

(GIF) Impact Factor: 0.549

IJFAS 2021; 9(5): 89-94

(C) 2021 IJFAS

www.fisheriesjournal.com

Received: 18-07-2021

Accepted: 25-08-2021

KM Abdul Halim

Department of Fisheries,

Ministry of Fisheries and

Livestock, Bangladesh

SM Rezaul Karim

Department of Fisheries,

Ministry of Fisheries and

Livestock, Bangladesh

Md. Asek Uddin

Department of Fisheries,

Ministry of Fisheries and

Livestock, Bangladesh

KM Hasanuzzaman

Department of Fisheries,

Ministry of Fisheries and

Livestock, Bangladesh

Md. Nawshad Ali

Department of Aquaculture,

Bangladesh Agricultural

University, Mymensingh,

Bangladesh

\section{SM Rahmatullah}

Department of Aquaculture,

Bangladesh Agricultural

University, Mymensingh,

Bangladesh

\section{Determination on fish diversity indices from Chalan Beel, Bangladesh}

\author{
KM Abdul Halim, SM Rezaul Karim, Md. Asek Uddin, KM \\ Hasanuzzaman, Md. Nawshad Ali and SM Rahmatullah
}

DOI: https://doi.org/10.22271/fish.2021.v9.i5a.2567

\begin{abstract}
An assessment was carried out to determine the fish diversity indices from Ruhul beel 1, 2 and Bamonji beel 1, 2 under Chalan beel in Pabna district of Bangladesh. Data were collected from selected sanctuary sites, focus group discussion, personal and group contract as well as Government and Non-Government organizations with prepared and pretested questionnaire. The fish diversity of the study areas was calculated by various methods namely Species richness $(\mathrm{S})$, Shannon-Wiener diversity indices $\left(\mathrm{H}_{0}\right)$, Species evenness (E) and Simpson's diversity Index (D) of fish observed in Ruhul beel and Bamonji beel during the whole study period. The highest species richness was found in Ruhul beel whereas it was less amount in Bamonji beel during the study period. Overall species richness was higher in Ruhul beel. The monthly species richness was significantly $(P<0.01)$ varied among the months. The highest values were found 37 in November and December for Ruhul beel-1 and in October and November for Ruhul beel-2. On the other hand, the highest value was found in November and December for Bamonji beel-1 and same value in November for Bamonji beel-2. The lowest values were found 13, 15, 9 and 8 for Ruhul beel-1, Ruhul beel-2, Bamonji beel-1 and Bamonji beel-2, respectively in January.
\end{abstract}

Keywords: Fish diversity indices, Chalan beel

\section{Introduction}

The Chalan beel was once the largest and best known of the beels in northern Bangladesh. Once upon a time it covered an area belonging to 26 Upazillas under 6 districts which was Natore, Pabna, Sirajgonj, Chapai Nawabgong, Naogon and Rajshahi district (DoF, 2011) ${ }^{[9]}$.

However, the beel is presently spreads concisely over mainly 10 Upazilas under three districts because of siltation and human interference. The included Upazillas are Singra, Gurudaspur and Boraigram under Natore district, Chatmohar, Bhangura and Faridpur under Pabna district, Shahjadpur, Ullapara, Tarash and Raigonj under Sirajgonj district (Hossain et al., 2008) ${ }^{[15]}$ although Galib et al., (2009) ${ }^{[10]}$ stated that now it is confined among 9 Upazilla under 4 districts.

The fishes are the most diverse and most abundant vertebrate in the world and about $40 \%$ of them live in freshwater (Hossain and Haque 2005) ${ }^{[14]}$. There are about 85 definitions of biodiversity one of which is; "Biological Diversity that is Biodiversity" means the variability among living organisms from all sources including, inter alia, terrestrial, marine and other aquatic ecosystems and the ecological complexes of which they are part; it includes diversity within species between species and of ecosystems. According to Natasha (2008) [26] "The word biodiversity is used to explain the variety of life on Earth, and is considered at different levels of biological organization including genes, species and ecosystems". Gaston and Spicer (2004) [11] defined biodiversity as "Biodiversity is the variety of life on earth and includes variation at all levels of biological organization from genes to species to ecosystems". "Biological diversity provides resources for food, construction and raw materials for industry. It provides the basis for improvement of the domesticated species; maintains functions of ecosystems, including evolutionary processes; stores and cycles nutrients essential for life; absorbs and breaks down pollutants, including organic waste, pesticides, and heavy metals; recharges ground water, protects catchment basins, and buffers extreme water conditions; and produces soil and protects it from excessive erosion" UNESCO (1994) ${ }^{[38]}$.
Corresponding Author: Department of Fisheries, Ministry of Fisheries and Livestock, Bangladesh 
We are continuously losing fish biodiversity in our country as well as in the whole world. With the degradation of the biodiversity society can be affected seriously specially the fisher-folk. Freshwater biodiversity has declined faster than either terrestrial or marine biology over the past 30 years (Vijaylaxmi et al., 2010) ${ }^{[40]}$. The fish diversity and production in Bangladesh decreased a lot in last few decades due to habitat destruction (Sayeed, 2010) ${ }^{[33]}$ by siltation of beelsrivers-canals, general reduction of floodplain and beel area, over exploitation, unplanned constructions of dams, regulators, culverts, cross roads and high ways which prevents the spawning, feeding and migration of fishes, embankments that cut off canals connecting the beels with rivers which is preventing replenishment of beels with fishes, indiscriminate use of pesticides and chemical fertilizers in agricultural land, excessive removal of surface water and extraction of ground water for irrigation, water pollution due to discharges of untreated effluents from industries like sugar mills, tannery, changes in cropping pattern and many other causes created by human interference. It was revealed by Department of Fisheries (DoF) that in this region fish output alone has declined by $60 \%$ during the last 15 years. As many as 51 fish species have become threatened and many fish are on the verge of extinction which was once abundant in beels.

\section{Materials and Methods}

2.1 Data Collection: Data was collected through weekly field survey from selected professional fishermen's catch in the study area during May 2012 to April 2014. The fishermen used 10 types of fishing gears to harvest fishes in the locality which were Nets (Badai jal, Current jal, Khora jal, Thela jal, Dhormo jal), Traps (Dhundi, Polo), Hooks (Borshi). Other than these gears they used to fish with bare hand (Hand fishing) and fishing by dewatering. In the afternoon the Current jal and traps (Dhundi) were fixed in the beel and early in the morning of next day the nets and traps were taken out from the beel water. Ber jal (seine net) was operated at late night for 3 to 5 hours with the professional fishers. Thela jal and Dhormo jal were used at day time for 3 to 6 hours and catch of 20 hauls were considered for each sample (Mohsin et al., 2013) ${ }^{[25]}$. A digital balance (measurable up to $0.01 \mathrm{~g}$ ) for small fish and pan balance for the bigger fishes were used to measure the amount of harvested sample individually (Hossain, 2010) ${ }^{[18]}$.

2.2 Species Count and Identification: The collected samples were counted on the spots those were easily identifiable species and the other species were brought to the laboratory by preserving in $10 \%$ formalin solution for farther analysis (Hasan et al., 2012) ${ }^{[13]}$. The species count was done by direct count method. Samples were divided into sub-sample when the amount of the samples was bigger than 200 individuals. Collected fish specimens were identified following Bhuiyan (1964), Rahman (1989), Rahman (2005) [29], Talwar and Jhingran (1991), Shafi and Quddus (2001) and Shahjahan et

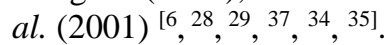

2.3 Data Analysis: The fish species diversity was analyzed using different indices (Vijaylaxmi et al., 2010) ${ }^{[40]}$ like Species Richness, Shannon-Weiner index (Shannon and Weaver 1949) ${ }^{[36]}$ Simpson's Diversity index (Krebs, 1978) ${ }^{[22]}$ and Pileups Evenness (Norton 2001, Zar, 1996) ${ }^{[27]}$. Species richness is simply the number of species present in an area. Species evenness refers to the proportion that each species comprises of the whole population (Kathleen et al., 2005) ${ }^{[21]}$. Shannon index is an important statistic index, which means it assumes all species are represented in a sample and that they are randomly sampled. The following procedures were considered to estimate the fish diversity which was as follows;

\subsection{Species Richness}

Species richness (Zar, 1966) ${ }^{[41]}$ is the number of different species present in an area. The more species present in a sample the 'richer' the area. It is expressed by ' $\mathrm{S}$ '.

$$
\text { That is, Species Richness }(\mathrm{S})=\sum_{i}^{s} p_{i}^{0}
$$

The higher value of ' $S$ ' indicates the higher diversity.

\subsection{Shannon-Wiener diversity index $\left(\mathrm{H}_{0}\right)$}

It combines species richness (S) and evenness (E), and also it is most commonly used diversity indices in ecology. The formula for calculating the index is as follows:

$$
\mathrm{H}_{0}=\underset{i}{\mathrm{i}=1} \underset{\mathrm{pi}}{\mathrm{S}} \ln \mathrm{pi}
$$

Where

$\mathrm{H}_{0}=$ the species diversity index,

$\mathrm{S}=$ the number of species, and

pi $=$ the proportion of individuals of each species belonging to the species of the total number of individuals (Kathleen $e t$ al., 2005) ${ }^{[21]}$.

The value of ' $\mathrm{H}_{0}$ ' ranges from 0 to 5 , usually ranging from 1.5 to 3.5. It interpreted as low values (within limit) of ' $\mathrm{H}_{0}$ ' indicates low diversity and that means the most individuals are concentrated in a few species, while high values (within limit) of ' $\mathrm{H}_{0}$ ' indicate greater diversity or greater evenness in the distribution of individuals among species. A positive change indicates increased diversity and evenness, a negative change indicates reduced diversity and evenness (Hunter, 1996 and Hossain et al., 1999) ${ }^{[19},{ }^{16]}$.

\subsection{Species Abundance or Evenness}

Species Abundance or Evenness is the relative abundance of species. It is expressed by ' $E$ ' and was calculated using the following formula:

Species Evenness $(\mathrm{E})=\mathrm{H}_{0} / \mathrm{H}_{\max }$

Here, $\mathrm{H}_{0}=\mathrm{Pi}(\ln \mathrm{Pi})=$ Shannon Wiener's Index.

$\mathrm{H}_{\mathrm{mx}}=$ Natural $\log (\ln )$ of Species richness $=\ln (\mathrm{S})$

The higher value of ' $E$ ' indicates the higher diversity. Values range from 0 to 1 .

2.7 Simpson's Diversity Index (D) $D=\frac{\sum \mathrm{n}_{i}\left(\mathrm{n}_{i}-1\right)}{\mathrm{N}(\mathrm{N}-1)}$

Where,

$n i=$ number of individuals or amount of each species (i.e., the number of individuals of the ith species) and

$N=$ total number of individuals for the site.

The value of ' $\mathrm{D}$ ' ranges from 0 to 1 . With this index, 0 represents infinite diversity and 1 no diversity. That is, the bigger ' $\mathrm{D}$ ' value (within limit) indicates the lower diversity (Source: Internet; Biodiversity, measuring biodiversity, 
student and teachers guide).

Simpson's diversity index is less sensitive to species richness and heavily weighted towards the most abundant species. Generally, less sensitive than Shannon-Weiner index ' $\mathrm{H}_{0}$ ' (Source: Internet; Measuring Species Diversity).

\section{Results}

Species richness, evenness and diversity are all fun concepts to teach biology students. But these are somewhat intuitive, easy to calculate and can be used to compare different populations (Kathleen et al., 2005) ${ }^{[21]}$. The fish diversity of the study areas was calculated by various methods which has been presented below (Table 1).

\subsection{Species Richness}

The highest ' $\mathrm{S}$ ' (species richness) value (38) was found for the RB whereas it was 37 for the BB during the study period. Overall species richness was higher in RB (Table 2). The monthly species richness was significantly $(P<0.01)$ varied among the months (Table 2). The highest values (37) were found in November and December for RB-1 and 37 in October and November for RB-2. The highest value (35) were found in November and December for BB-1 and same value in November for BB-2. The lowest values were found 13, 15,
9 and 8 for RB-1, RB-2, BB-1 and BB-2, respectively in January (Figure 1).

\subsection{Shannon-Wiener Diversity Indices $\left(\mathrm{H}_{0}\right)$}

The highest Shannon-Wiever diversity indices $\left(\mathrm{H}_{0}\right.$ value $)$ were recorded in RB-2 (2.97430) followed by RB-1 (2.33668). The lowest $\mathrm{H}_{0}$ value was calculated in BB-2 (1.43806). According to Shannon Weiner indices $\left(\mathrm{H}_{0}\right)$ fish diversity was increased in RB.

\subsection{Species Abundance or Evenness (E)}

The ' $E$ ' value was $0.64072,0.81766,0.46637$ and 0.40130 for RB-1, RB-2, BB-1 and BB-2, respectively. From the 'E' value it was revealed that fish diversity was increased in RB2. On the other hand, ' $E$ ' value was decreased in Bamonji beel i.e. fish diversity decreased in BB-2 than BB-1.

\subsection{Simpson's Diversity Index}

The ' $\mathrm{D}$ ' value was $0.14445,0.13938,0.15538$ and 0.14032 at RB-1, RB-2, BB-1 and BB-2, respectively. The 'D' values indicate that fish diversity increased in RB-2 from RB-1 that is fish diversity was higher in RB-2. On the other hand, fish diversity was decreased in BB-2.

Table 1: Calculative value of Species richness (S), Shannon-Wiener diversity indices $\left(\mathrm{H}_{0}\right)$, Species evenness (E) and Simpson's diversity Index (D) of fish and prawn observed in RB and Bamonji beel during the whole study period

\begin{tabular}{|c|c|c|c|c|}
\hline Month & $\mathbf{S}^{\mathbf{1}}$ value & $\mathbf{H}_{\mathbf{0}}^{\mathbf{2}}$ value & $\mathbf{E}^{\mathbf{3}}$ value & $\mathbf{D}^{\mathbf{4}}$ value \\
\hline RB-1 & 38 & 2.33668 & 0.64072 & 0.14445 \\
\hline RB-2 & 38 & 2.97430 & 0.81766 & 0.13938 \\
\hline BB-1 & 37 & 1.67125 & 0.46637 & 0.15538 \\
\hline BB-2 & 37 & 1.43806 & 0.40130 & 0.14032 \\
\hline
\end{tabular}

1. $\mathrm{S}=$ Species richness the higher value of ' $\mathrm{S}$ ' indicates the higher diversity.

2. $\mathrm{H}_{0}=$ Shannon Wiener index. The higher value of ' $\mathrm{H}_{0}$ ' indicates the higher diversity. Values range from 0 to 5 , usually ranging from 1.5 to 3.5

3. $\mathrm{E}=$ Species evenness; the higher value of ' $\mathrm{E}$ ' indicates the higher diversity. Values range from 0 to 1 .

4. $\mathrm{D}=$ Simpson's index. The lower value of ' $\mathrm{D}$ ' indicates the higher diversity. The value of ' $\mathrm{D}$ ' ranges from 0 to 1 . With this index, 0 represents infinite diversity and, ' 1 ' represents no diversity. That is, the bigger the value the lower the diversity.

Table 2: Correlations of fish numbers with inter month, inter gear and inter year

\begin{tabular}{|c|c|c|c|c|c|c|}
\hline & & Site & Year & Month & Gear & Fish amounts \\
\hline \multirow{2}{*}{ Site } & $\mathrm{PC}^{1}$ & 1 & & & & \\
\hline & Sig. (2-tailed) & & & & & \\
\hline \multirow{2}{*}{ Year } & PC & -.022 & 1 & & & \\
\hline & Sig. (2-tailed) & .119 & & & & \\
\hline \multirow{2}{*}{ Month } & $\mathrm{PC}$ & .008 & $.075(* *)$ & 1 & & \\
\hline & Sig. (2-tailed) & .591 & .000 & & & \\
\hline \multirow{2}{*}{ Gear } & PC & $.058(* *)$ & .018 & $.090(* *)$ & 1 & \\
\hline & Sig. (2-tailed) & .000 & .206 & .000 & & \\
\hline \multirow{2}{*}{ Fish amount } & PC & $-.148(* *)$ & $.036(*)$ & $-.072(* *)$ & $.079(* *)$ & 1 \\
\hline & Sig. (2-tailed) & .000 & .011 & .000 & .000 & \\
\hline
\end{tabular}

\subsection{Monthly Variation in Fish Diversity Indices (S) in Different Sites and Years.}

The highest fish diversity was recorded in the month of November for both the beels in both the years. The lowest fish diversity was recorded in the month of January for both the beels in both years. However, there was no catch in the month of March in both the beels. 


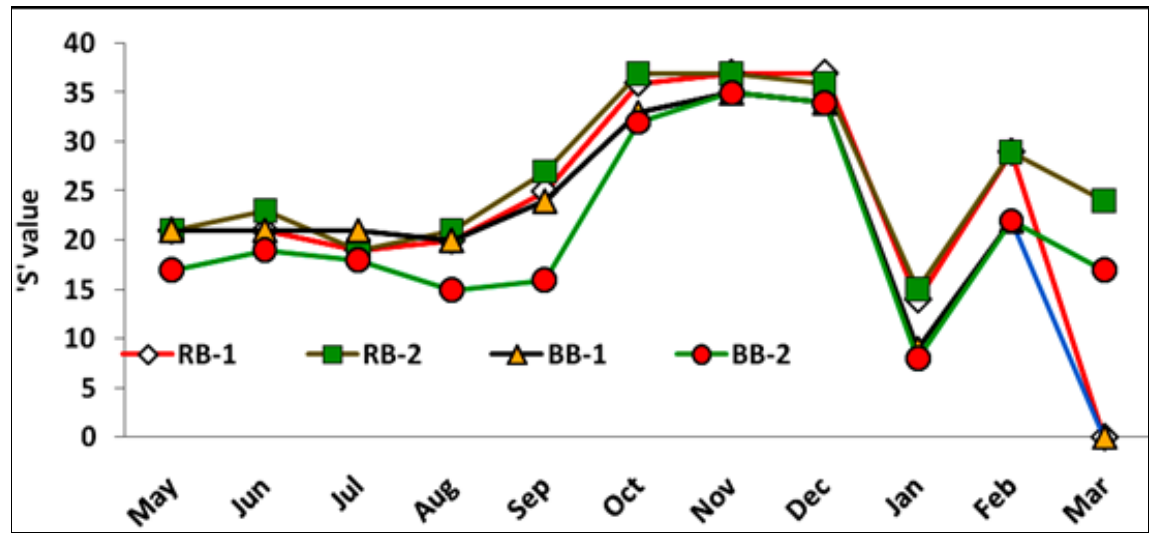

Fig 1: Trends of monthly variation in diversity index (Species richness) in different site during the whole study period.

\section{Discussion}

The present study revealed that overall total species richness for RB and Bamonji beel were 38 and 37, respectively which was closely related to the results of Vanderpuye (1982), Dankwa (1982) and Antwi and Ofori-Danson (1993) $\left.{ }^{[39},{ }^{8}, 3\right]$. Overall species richness was higher in RB during the study period. It was might be due to the establishment of sanctuary which protect the fishes from over exploitation and create shelter, spawning ground, feeding ground which ultimately increase the species richness. The result of present study was more or less similar with the findings of Aliko et al. (2010) ${ }^{[2]}$, who showed the species richness at riverine zone was 42,43 for the transitional zone, 45 for the lacustrine, 33 for the transitional zone and 18 for riverine and lacustrine zones. The result was also more or less relevant to the findings of Saha and Hossain (2002) ${ }^{[32]}$. However, the findings of present study were differed from the findings of Sayeed (2010), Biswas and Sugunan (2005), Azhar (2009), Saha and Hossain (2002), BFRI (2002) and Hossain et al., (1999) ${ }^{[32},{ }^{33}, 37,7,4,32$, $5,16]$.

The species richness was increased in RB after establishing the sanctuary which is supported by the findings of Hasan et al. (2012), Rahman et al., (1999), Kadir et al. (1999) and MACH $(2001)^{[13},{ }^{30},{ }^{20},{ }^{24]}$.

The fish diversity of species in a particular area depends on not only the number of species found, but also in their

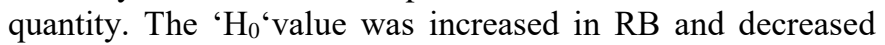
for $\mathrm{BB}$ which indicates that the fish diversity was increased in sanctuary (RB) site and decrease in the control site which is supported by Azher (2009) and Hossain et al., (1996) ${ }^{[4,13]}$.

Rahman (2009) ${ }^{[31]}$ observed that the $\mathrm{H}_{0}$ value was varied from 0.46 to 1.03 in three beels under Rangpur district which was lowed that the present study. Syeed (2010) ${ }^{[33]}$ showed Shannon Index $\left(\mathrm{H}_{0}\right)$ varied between 3.13 and 3.44 which were closely related to the present study.

From the calculated value of ' $\mathrm{E}$ ' it was observed that the overall fish more diversification in RB. It was revealed that the fish diversity was shown decreasing trends in BB. In the meantime, overall fish diversity showed increasing trends in RB. So it is concluded that diversity of RB was increased might be due to the sanctuary setup in the locality.

In the present study, the increasing trends of species evenness or relative abundance (E) and decreasing trends of ' $D$ ' value indicates the higher fish diversification for RB during the whole study period. Sayeed (2010) ${ }^{[33]}$ also showed that the value of species evenness varied between 0.72 and 0.76 at different sites under his study. So the findings of the present study were supported by many other researchers.

The monthly species richness was significantly $(P<0.001)$ varied among the months. The highest fish diversity was found in the month of November in both the beels which might be due to high abundance of fish, suitable water level and god weather condition for fish and fishing which is supported by the results of Hallier and Kulbicki (1985) ${ }^{[12]}$ who showed that the Seasonal variations in Leiognathidae are known to exist in New Caledonia and the tuna live bait fishery in the bay St Vincent has maximum catches of fish (mainly L. bindus) during the dry season between August and November. In Bangladesh, these species showed strong seasonal fluctuations with two peaks of abundance (AprilMay and November-December) that correspondent to the beginning and end of the dry season (Lamboeuf, 1987) ${ }^{[23]}$. The lowest fish diversity was recorded in the month of January in both beels and in both the years which might be due to very cold situation and normally fishers were reluctant to operate traps (especially Dhundi). Aliko et al. (2010) ${ }^{[2]}$ also found the seasonal variation at the riverine zone, at transitional zone and lacustrine zone.

Considering all the recorded data it was found that the fish diversity was higher in RB than other site in both years. All diversity indexes (i.e. value of $\mathrm{S}, \mathrm{H}_{0}, \mathrm{E}$ and $\mathrm{D}$ ) showed that fish diversity was gradually increased RB which might be due to the sanctuary establishment.

The total number of species was not increase in the beels because there has a barrier to connect the beels with the rivers and canals. The abundance and production of fish species were tightly bound to the flooding pattern during the monsoon season (Ahmed and Singh, 1991) ${ }^{[1]}$.

\section{Conclusion}

There are a series of small beel under the Chalan beel which is quite different from biodiversity, water depth, hydrography, physico-chemical characteristics and biological conditions. Fish species richness were higher in Ruhul beel. The monthly species richness was significantly varied among the months. The highest values were found in November and December for Ruhul beel-1 and 37 in October and November for Ruhul beel-2. On the other hand, the highest value were found in November and December for Bamonji beel-1 and same value in November for Bamonji beel-2. The lowest values were found 13, 15, 9 and 8 for Ruhul beel-1, Ruhul beel-2, Bamonji beel-1 and Bamonji beel-2, respectively in January.

\section{Acknowledgement}

The authors are grateful to Ministry of Fisheries and Livestock, Government of the Peoples' Republic of Bangladesh for financial support to carry out the study. 


\section{Conflict of interests}

The authors declare that there is no conflict of interests regarding the publication of this paper.

\section{References}

1. Ahmed SH, Singh AK. Fishery development in oxbowlakes ('Mans') of Bihar. Fishing Chimes 1991;11(3):5962.

2. Aliko NG, Costa KSD, Konan KF, Ouattara A, Gourene G. Fish Diversity Along the Longitudinal Gradient in A Man-Made Lake of West Africa, Taabo Hydroelectric Reservoir, Ivory Coast, Ribarstvo 2010;68(2):47-60.

3. Antwi LAK, Ofori-Danson PK. Limnology of a tropical reservior (The kpong reservior in Ghana). Trop. Ecol 1993;34(1):75-87.

4. Azhar SA. Impact of fish sanctuary on production and biodiversity of Aquatic Organisms in Rivers and Beels of Haor Area. PhD dissertation. Department of Fisheries Management, Bangladesh Agricultural University, Mymensingh, 2009.

5. BFRI (Bangladesh Fisheries Research Institute) SylhetMymensingh Basin Fish Stock Assessment. Final Report. Bangladesh Fisheries Research Institute, Riverine Station, Chandpur, Bangladesh, 2002, 29-35.

6. Bhuiyan AL. Fishes of Dacca, Asiat. Soc. Pakistan, Pub. 1, No. 13, Dacca (Dhaka), 1964.

7. Biswas BK, Sugunan VV. Fish diversity of Brahmaputra basin in Assam. Abstracts of National Seminar on Management Challenges in Fisheries of Rivers and associated Ecosystem: Issues and strategies, April16-17, 2005, Barrackpore, Kolkata, India, 2005, 59.

8. Dankwa HR. Fish fauna of the Kpong headpond one year after impoundment. Technical Report, Institute of Aquatic Biology, Accra, Ghana, 1982.

9. DoF. (Department of Fisheries) Fish week Compendium. Department of Fisheries, Ministry of Fisheries and Livestock, Dhaka, Bangladesh, 2011.

10. Galib SM, Samad MA, Mohsin ABM, Flowra FA, Alam MT. Present status of fishes in the Chalan Beel- the largest beel (wetland) of Bangladesh. International Journal of Animal and Fisheries Science 2009;2(3):214218.

11. Gaston KJ, Spicer JI. Biodiversity an introduction. 2nd Edition. Blackwell Publishing Asia Pty Ltd. 2004.

12. Hallier JP, Kulbicki M. Analyse des résultats de la pêcherie lai canne de Nouvelle-Calédonie. (Aoilt 1981Avril 1983). Rapport Scientifique et Technique No. 36. (ORSTOM: Nouméa.) 1985.

13. Hasan MANGM, Lucky NS, Hossain MAR. Natural Food Abundance and SIS Biodiversity of Matshaya Rani Fish Sanctuary, Department of Fisheries Biology and Genetics, Bangladesh Agricultural University, Mymensingh, J Environ. Sci. and Natural Resources 2012;5(1):319-328.

14. Hossain MA, MA Haque. Fish species composition in the River Padma near Rajshahi. Journal of Life Earth Science 2005;1(1):35-42.

15. Hossain MAR, Nahiduzzaman M, Sayeed MA, Azim ME, Wahab MA, Olin PG. The Chalan beel in Bangladesh: Habitat and biodiversity degradation, and implications for future management. 2008, 13.

16. Hossain MS, Ehshan MA, Mazid MA. Fish biodiversity study of three floodplains in Bangladesh. In: Sustainable Inland Fisheries Management in Bangladesh. Hans AJ,
Middendorp PM, Thompson Pomeroy RS (eds.). ICLARM, Danida and Ford Foundation, Bangladesh 1999, 229-233.

17. Hossain MT, Ehshan MA, Uddin MA. Biodiversity study of the floodplains in Bangladesh. In: Sustainable Inland Fisheries Management in Bangladesh. Hans AJ Middendorp PM, Thompson RS. Pomeroy (eds.). ICLARM, Danida and Ford Foundation, Bangladesh 1996, 229-233.

18. Hossain MY. Morphometric Relationships of LengthWeight and Length-Length of Four Cypriinid Small Indigenous Fish Species from the Padma River (NW Bangladesh), University of Rajshahi, Faculty of Agriculture, Department of Fisheries, Rajshahi 6205, Bangladesh, Turkish Journal of Fisheries and Aquatic Sciences 2010;10:131-134

19. Hunter ML. Fundamentals of Conservation Biology. Department of Wildlife Ecology, University of Main, Oranto 1996, 32-61.

20. Kadir MM, Hossain MM, Kabir MS. Patterns of fish catches in rivers and open beels. Paper presented in the National Workshop on Community Based Fisheries Management and Future Strategies for Inland Fisheries in Bangladesh. 1999, Dhaka, Bangladesh 1999, 45-50.

21. Kathleen AN, Callahan JE.: Beachcomber Biology: The Shannon-Weiner Species Diversity Index, ABLE 2005 Proceedings St. Francis College, 180 Remsen St., Brooklyn, NY 11201 2005;27:718-489-5439.

22. Krebs CJ. Ecology: The experimental analyses of distribution and abundance. (2 ${ }^{\text {nd }}$ Edition). New York: Harper and Row Publishers, 1978.

23. Lamboeuf M. Bangladesh demersal fish resources of the continental shelf. RN Anasandhani trawling survey results. September 1986. FI: DP/BGD/80/025. (FAOAJNDP Project. Strengthening of the National Programme for Marine Fisheries Resources Management, Research and Development. FAO: Rome.)

24. MACH (Management of Aquatic-Ecosystems Through Community Husbandry) Third Annual Report. Dhaka, Bangladesh, In: Uddin, K. and A. Munir (ed.), Fish Sanctuary (Necessity, Concepts, Practices and Prospects), 2002. Bangladesh, Dhaka, 2002, 124.

25. Mohsin ABM, Haque MSM, Galib SM, Fahad MFH, Chaki N, Islam MN. Seasonal Abundance of Fin Fishes in the Padma River at Rajshahi District, Bangladesh, Department of Fisheries, University of Rajshahi, Rajshahi-6205, Bangladesh, World Journal of Fish and Marine Sciences 2013;5(6):680-685.

26. Natasha de Vere. Biodiversity, EDIT Summer School 2008 Modern Taxonomy and Field Work National Botanic Garden of Wales, Lanarthne, Carmarthenshire, SA32 8HG, UK 2008. ndevere@ gardenofwales.org.uk

27. Norton FA. A rough guide to PPAs: Participatory Poverty Assessments, an Introduction to Theory and Practice, ODI, London, 2001.

28. Rahman AKA. Freshwater Fishes of Bangladesh, 1st edition, Zoological Society of Bangladesh, Department of Zoology, University of Dhaka, Dhaka 1000: 1989, 364.

29. Rahman AKA. Freshwater fishes of Bangladesh, 2nd ed., Zoological Society of Bangladesh, Department of Zoology, University of Dhaka, Dhaka-1000. Bangladesh 2005, 394.

30. Rahman M, Capistrano DA, Minkin SF, Islam A, Holder S. Experience of community managed wetland habitat 
restoration. In: Sustainable inland fisheries management in Bangladesh. H. A. J. Middendrop, P. M. Thompson and R. S. Pomeroy (eds). Proc. Conf. ICLARM No. 58, Manila 1999, 111-121.

31. Rahman MZ. Impact of distillery and agricultural pollution on physico-chemical and biological features of three natural reservior (Beel) of Rangpur in Bangladesh. Ph.D. Dissertation, Dept. of Fisheries Biology and Genetics, Bangladesh Agricultural University, Mymensingh 2009, 189.

32. Saha BK, Hossain MA. Saldu Beel fishery of Tangail, Bangladesh. J Zool 2002;30(2):187-194.

33. Sayeed MA. Fish Biodiversity in the Chalan beel, A Depression in North West Bangladesh. A Ph.D. Dissertation, Submitted to the Bangladesh Agricultural University, Mymensingh, Department of Fisheries Biology and Genetics, 2010.

34. Shafi M, Quddus MMA. Bangladesher Matsho Shampad (Fisheries of Bangladesh), (in Bengali), Kabir publication. Dhaka, Bangladesh, 2001.

35. Shahjahan M, Miah MI, Haque MM. Present Status of Fisheries in Jamuna River, Pakistan J Biol. Sci 2001;4(9):1173-1176.

36. Shannon CE, Weaver W. A mathematical theory of communication. The Bell System Technical Journal, 1949, 379-423, 623-656.

37. Talwar PK and Jhingran AG. Inland Fishes of India and Adjacent Countries, Oxford and IBH Publishing Co. Pvt. Ltd. New Delhi-Calcutta, 1991, 1(2).

38. UNESCO. Science Conservation and Sustainable Use. Biodiversity No. 7. Paris, 1994.

39. Vanderpuye CJ. Pre-impoundment fish fauna of the Kpong hydroelectrical project area, lower Volta, Ghana. Bulletin de 1 I.F.A.N.T. 44 ser. A, 1982;3(4):365-383.

40. Vijaylaxmi C, Rajshekhar M, Vijaykumar K. Freshwater fish distribution and diversity status of Mullameri River, a minor tributary of Bheema River of Gulbarga District, Karnataka, International Journal of Systems Biology, ISSN: 0975-2900, 2010;2(2):01-09.

41. Zar JH. Biostatistical analysis. (3rd Edition) London: Prentice-Hall 1996. 